gravity was in excess, as is usual on oceanic islands; upon the ice it was nearly normal, which confirms the results of Dr. Hecker's recent determinations of gravity at sea. The observations on the ice were of the heroic order, from difficulty, not with the pendulums, but with the clocks. An ice pillar proved nearly as stable as concrete for the pendulums, but the chronometer stopped at a temperature of $-35^{\circ} \mathrm{C}$., and the clock was filled with snow in the rather inadequate observing hut. The clock was then removed to the ship and connected with the "flash box" by cable; but the ship heeled over in an Antarctic gale, and again the clock stopped. Finally, after six months' work, it was installed in an ice house, when it went creditably.

The discussion of the observations, largely due to Prof. Haasemann, is full of interest, but the interest lies, unfortunatcly, in the details of the struggle against adverse circumstances rather than in the wealth of results. It is much to be regretted that Dr. Drygalski's pendulums failed to reach land within the Antarctic circle, for it may be long before so complete an equipment and so accomplished an observer travels again to that sector of the Antarctic.

A. R. H.

\section{A NEW OCEANOGRAPHICAL EXPEDITION.}

THE Times of November 9 announces the organisation of an important expedition for the investigation of the eastern part of the North Atlantic Ocean, with a possible extension westward to Newfoundland. By an Order in Council, dated October I6, his Majesty the King of Norway has granted permission, subject to certain conditions, for the Norwegian Government steamer Michael Sars " to be placed gratuitously at disposal for a scientific expedition in the Atlantic Ocean from the Canary islands to the Frööes, in the spring of I9Io, proposed by a British subject, Sir John Murray," and also for " the Fishery Director, Dr. Hjort, Assistant Koefoed, and Mr. Helland-Hansen, as well as the ship's captain and engineer... to take part in the expedition while continuing to draw their salaries."

The Michael Sars is to sail under the Norwegian flag during the expedition, which is to extend over not more than four months, and Sir John Murray has undertaken to pay all expenses not provided for by the Order in Council.

The chief purpose of the forthcoming expedition, which must necessarily contribute results of first-rate importance to the science of oceanography, is to apply the new instruments and methods of research developed during the last few years, more particularly by the International Council for the Study of the Sea, to the deeper regions of the open ocean. It is believed that the use of large nets and trawls is practicable in deep water, and that, should this prove to be the case, zoological discoveries of great interest and importance will be made. The application of methods of high precision to the determination of the temperature and salinity of sea water has yielded results which have raised considerable doubt in the minds of some investigators as to the validity of the earlier observations made by the Challenger and other expeditions, and the cruise of the Michael Sars should not only afford much entirely new information, but provide a means of valuing the earlier work. Specially valuable data may be expected from the use of Ekman's new current-meter, which makes it possible for the first time to obtain direct measurements of the currents in the depth.
THE REV. W. H. DALLINGER, F.R.S.

$\mathrm{IN}$ the history of "Protozoology"-a department which has advanced of late so rapidly that it has journals, laboratories, and professorial chairs devoted to it-an honoured place, in one of the earlier chapters, must be given to the late Dr. Dallinger, for to him and to his fellow-worker, the late Dr. Drysdale, we owe the first complete record of a complex Protistan life-history, and at the same time a fine example of careful investigation.

William Henry Dallinger was born in 1842 at Devonport. He entered the Wesleyan ministry in I86I, and travelled various circuits, much esteemed as an impressive and weighty preacher. A serious illness is said to have driven him from theology to biology, for in his convalescence he took up the study of open-air natural history, and became fascinated with microscopic work. In 1880 he was appointed principal of the Wesley College, Sheffield, but he resigned this position in I 888 to devote himself more exclusively to scientific work, the Wesleyan Conference allowing him to retain his status and prerogatives as a minister, though without pastoral charge or any other office. Dallinger did much effective work as a lecturer on the staff of the Gilchrist Educational Trust, and his popular lectures on such subjects as "The Infinitely Little," "An Hour with the Microscope," and "Spiders," were models of clear expnsition. He had a vivid and careful style, and give his delighted audiences a sound mixture of accurate facts and suggestive ideas. A good instance was the lecture on "The Lowest and Smallest Forms of Life," which he delivered on the occasion of the Montreal meeting of the British Association in 1884 . For manv years. Dr. Dallinger was secretary of the Rovai Microscopical Society, and he occupied the presidentiat chair from 1883 to 1887 . He took a great interest in this society and in its valuable journal. It is said that during his presidency he travelled to attend the meetings a distance equal to about half the circumference of the globe, and it was characteristic of his conscientiousness that he usually journeyed back from London to Sheffield by the early mail train so as to be in time for his college duties in the morning.

Dallinger's scientific work began about i 870 , and in $1873^{-6}$ he published, along with Drysdale, a series of papers on the life-history of monads in the Monthlv Micrescopical Journal. The characteristic feature of the patient labours of the two friends was continuity of observation. By means of a delicate mechanical stage and other devices they were able to keep their eye on one particular specimen of Bodo saltans, or whatever the flagellate might be, and follow it from phase to phase. By using a binocular they were able to change places without losing sight of the particular creature the life-cycle of which was being traced. On one occasion Dr. Dallinger kept up continuous observation for nine hours. The result was that some complete life-histories were worked out-spore-formation, growth of spores into flagellates, repeated fission of flagellates, conjugation, encysting, and spore-formation again. This was interesting in itself, it was prophetic of much that has followed in recent years, and it exposed one of the pitfalls in which believers in present-day abiogenesis are apt to come to grief.

In connection with the spontaneous generation auestion - which has had so many fruitful resultsDrysdale and Dallinger made some interesting studies, showing, for instance, that although boiling the water killed monads in an active condition, it did not kill the spores. For the spores, indeed, the fatal temperature is very much higher, up to $268^{\circ} \mathrm{F}$. 